Accessed on: http://jkb.ub.ac.id/index.php/jkb/article/view/2548

Jurnal Kedokteran Brawijaya Vol. 31, No. 1, Februari 2020, pp. 1-6

Article History: Received 14 March 2019, Accepted 10 September 2019

Research Article

\title{
The Effects of Thyme on IL-6 Level and the Bacterial Count in the Brain and Spleen of Mice Infected by Methicillin-Resistant Staphylococcus aureus (MRSA)
}

\section{Pengaruh Thyme terhadap Kadar IL-6 dan Hitung Kuman pada Otak dan Limpa Mencit yang Diinfeksi Methicilin-Resistant Staphylococcus aureus (MRSA)}

\author{
Lisayani Prasetyowati ${ }^{1}$, Muchlis Achsan AS ${ }^{2}$, Helmia Farida ${ }^{3}$, Galuh Yulieta ${ }^{4}$ \\ ${ }^{1}$ Department of Blomedicine Faculty of Medicine Universitas Diponegoro Semarang \\ ${ }^{2}$ Department of Biomedicine and Tropical Diseases Faculty of Medicine Universitas Diponegoro Semarang \\ ${ }^{3}$ Department of Biomedicine and Microbiology Faculty of Medicine Universitas Diponegoro Semarang \\ ${ }^{4}$ Department of Microbiology Faculty of Medicine Universitas Diponegoro Semarang
}

\begin{abstract}
The extensive and irrational use of antibiotics causes resistance problems such as Methicillin-Resistant Staphylococcus aureus (MRSA). Widespread bacterial resistance to the existing antibiotics promotes the importance of discovering antibacterial sources or modulating the immune response from natural ingredients. This study aimed to reveal the potential of thyme (Thymus vulgaris) extract in reducing IL-6 level and MRSA bacterial count in the brain and spleen of Balb $c$ mice infected by MRSA. The design of this study was a randomized post-test control group. This study used 30 male $B A L B / c$ mice infected by MRSA and randomly divided into six groups. Measurement of IL-6 level was carried out using ELISA. The MRSA count was done by assessing the number of CFU per gram of tissue. There were no bacteria in the spleen tissue of all the groups. The IL-6 level in BALB/C mice infected with MRSA and treated with Thymus vulgaris was higher compared to those without Thymus vulgaris $(p<0,005)$. The greatest decrease in microbial count in the brain was among groups that were given the combination of thyme and amoxicillin. Thymus vulgaris extract can elevate the antibacterial effectiveness of amoxicillin.
\end{abstract}

Keywords: Counting MRSA bacterial, ELISA, IL-6, Methicillin-Resistant Staphylococcus aureus, Thymus vulgaris

\section{ABSTRAK}

Penggunaan antibiotik secara luas dan tidak rasional menyebabkan problem resistensi seperti Methicilin Resistant Staphylococcus aureus (MRSA). Meluasnya resistensi bakteri terhadap antibiotika yang ada, mendorong pentingnya penggalian sumber antibakteri dan modulator respon imun yang berasal dari bahan alam. Penelitian ini bertujuan untuk membuktikan potensi ekstrak Thyme (Thymus vulgaris) dalam menurunkan kadar IL-6 dan hitung kuman MRSA pada otak dan limpa mencit Balb c yang diinfeksi MRSA. Desain penelitian ini adalah "Randomized post test with control group". Penelitian ini menggunakan 30 ekor Mencit Balb/c jantan yang diinfeksi MRSA dan dibagi secara acak dalam enam kelompok. Pengukuran kadar IL-6 dilakukan menggunakan ELISA. dan hitung kuman MRSA dihitung dengan cara melihat jumlah CFU/gram jaringan. Tidak ditemukan kuman pada jaringan limpa mencit semua kelompok. Kadar IL-6 pada otak mencit Balb/c yang diinfeksi MRSA dan diterapi Thymus vulgaris lebih tinggi dibandingkan yang tidak mendapatkan Thymus vulgaris $(p<0,005)$. Penurunan paling besar dalam hitung kuman pada otak terjadi di kelompok yang diberikan kombinasi thyme plus amoksisilin. Ekstrak Thymus vulgaris dapat meningkatkan efektivitas antibakterial amoksisilin.

Kata Kunci: Counting MRSA bacterial, ELISA, IL-6, Methicillin-Resistant Staphylococcus aureus, Thymus vulgaris

Correspondence: Lisayani Prasetyowati. Department of Blomedicine Faculty of Medicine Universitas Diponegoro Semarang, Jl. Prof. Soedarto, Tembalang, Semarang 1269 Tel. (024) 7460041 Email: lisayani_17@yahoo.co.id

DOI: http://dx.doi.org/10.21776/ub.jkb.2020.031.01.1 


\section{INTRODUCTION}

The extensive and irrational use of antibiotics causes resistance problems. The discovery of antibiotics since 2000 has not been equal with the increasing number of antibiotic resistances that cause Multidrug-Resistant Organisms. One of the Multidrug-Resistant Organisms (MDROs) is Methicillin-Resistant Staphylococcus aureus (MRSA), which is resistant to methicillin antibiotics, such as amoxicillin (1). Immune system plays an important role in dealing with infections caused by $\mathrm{S}$. aureus. Immunostimulators that can stimulate proinflammatory cytokines, such as IL-6, have the potential to overcome resistant bacterial infections that pass through the immune system's defenses at the early stage. IL-6 production can increase the activity of macrophage phagocytosis, so the elimination of extracellular bacteria occurs more quickly (2).

Antibiotics are used to increase the bacteria elimination in acute infections. The antibiotic chosen for MRSA therapy in recent years is vancomycin. The use of vancomycin is still effective for the treatment of MRSA infections. Vancomycin is active against aerobic Gram-positive and anaerobic bacteria such as Staphylococcus, Streptococcus, Enterococcus, Clostridium spp, and Corynebacterium spp. Vancomycin is a slow bactericidal against $\mathrm{S}$. aureus and S.epidermidis. Amoxicillin is an antibiotic known to be resistant to Staphylococcus aureus. In this study, Amoxicillin was used to observe the effectiveness of amoxicillin combined with thyme in eliminating MRSA bacteria (3).

Widespread bacterial resistance to existing drugs encourages the importance of extracting antibacterial sources from natural substances or which modulate immune responses. The herbs examined in this study were Thymus vulgaris (thyme) because of their ease and active ingredients. Thyme (Thymus vulgaris) is very easy to find in Indonesia, one of which is in the Tawangmangu herbal plantation in Central Java. Thyme was chosen because the most active ingredients are carvacrol and thymol which have been proven to have effective antibacterial and immunostimulatory properties $(4,5)$.

\section{METHOD}

\section{Research Samples}

The research sample was male mice Balb/c aged 8 weeks old, weighed 20-30 grams. Mice were obtained from the Laboratory of Biology, Faculty of Mathematics and Natural Sciences, Semarang State University. The selected mice were Balb/c strain male mice, aged 8 weeks, weighed 2030 grams after acclimation, and no anatomical abnormalities were seen. Mice were not included in the study if they did not actively move or appeared ill before MRSA inoculation. The sample size according to WHO is that each group consists of at least 5 animals with a reserve of 10\%; in this study, the number of samples used in each group was 5 mice (6). Mice adaptation and treatments were carried out at the Parasitology Laboratory of Diponegoro University, Semarang. The handling of experimental animals in this study was in accordance with animal ethics, which was obtained by applying for approval to the Health Research Ethics Commission of the Faculty of Medicine, Diponegoro University, Semarang before the study began (7).

\section{Research Design}

This study was a laboratory experimental study with a Posttest only control group design. Mice were randomized using simple random sampling. The research groups were divided into six, namely three control groups and three treatment groups. The negative control group (K1) was a group of mice that had been adapted for 16 hours and then infected with MRSA ATCC $43300 \quad 0.2 \mathrm{ml} \quad\left(10^{7} \mathrm{cfu} / \mathrm{ml}\right)$ intraperitoneally followed by administering distilled water at a dose of $0.1 \mathrm{ml}$ intraperitoneally. The control group 2 (K2) was a group of mice that had been adapted for 16 hours and then infected with MRSA ATCC $433000.2 \mathrm{ml}$ $\left(10^{7} \mathrm{cfu} / \mathrm{ml}\right)$ intraperitoneally followed by the administration of vancomycin antibiotic therapy $2 x$ per day at a dose of $0.1 \mathrm{ml}$ intraperitoneally. Control group 3 (K3) was a group of mice that had been adapted for 16 hours and then infected with MRSA ATCC $433000.2 \mathrm{ml}\left(10^{7} \mathrm{cfu} / \mathrm{ml}\right)$ intraperitoneally followed by intraperitoneal administration of amoxicillin antibiotic therapy $3 x$ per day at a dose of $0.2 \mathrm{ml}$.

Treatment group 1 (P1) was a group of mice that had been adapted for 16 hours and then given Thymus vulgaris extract $1 x$ per day at a dose of $200 \mathrm{mg} / \mathrm{kg}$ BW/day orally or $0.3 \mathrm{ml}$ oral administration for seven days and then infected with MRSA ATCC $433000.2 \mathrm{ml}\left(10^{7} \mathrm{cfu} / \mathrm{ml}\right)$ on the seventh day intraperitoneally. Treatment group 2 (P2) was a group of mice that have been adapted for 16 hours and then given Thymus vulgaris extract $0.3 \mathrm{ml}$ orally for seven days and infected with MRSA ATCC $433000.2 \mathrm{ml}\left(10^{7} \mathrm{cfu} / \mathrm{ml}\right)$ on the seventh day intraperitoneally followed by intraperitoneal vancomycin antibiotic therapy $2 x$ per day dose of $0.1 \mathrm{ml}$. Treatment group 3 (P3) was a group of mice that had been adapted for 16 hours and given Thymus vulgaris extract $0.3 \mathrm{ml}$ orally once a day for seven days and infected with MRSA ATCC $433000.2 \mathrm{ml}\left(10^{7} \mathrm{cfu} / \mathrm{ml}\right)$ on the seventh day intraperitoneally followed by intraperitoneal amoxicillin antibiotic therapy $3 x$ per day at a dose of $0.0013 \mathrm{ml}$.

\section{Research Procedure}

\section{Preparation of Thyme (Thymus Vulgaris) Extract}

The production of thyme extract was carried out at the Integrated Laboratory Technical Implementation Unit (UPTLT), Diponegoro University (UNDIP) Semarang. Dried thyme leaf simplicia was dissolved with methanol, and thyme extract was made by maceration with a percolator and obtained 146.25gram thyme extract in paste form. Thyme paste was dissolved using Carboxy Methyl Cellulose (CMC) solvent so that it could be given to mice orally. The identification of Thymus vulgaris extract content from Gas Chromatography-Mass Spectrometry (GC-MS) analysis UNDIP UPTLT were thymol (Phenol, 5-methyl-2- (1methylethyl) - (CAS) $72.95 \%$ and carvacrol $4.23 \%$ (Phenol, 2-methyl-5- (1-methylethyl) - (CAS) (7,8).

\section{Blood Isolation and Enzyme Link Immunosorbent Assay} (ELISA) Examination

Blood isolation for IL-6 level measurement was taken 42 hours after MRSA infection. After termination using ether and vertebral dislocation, blood samples were taken from the retroorbital plexus orbital as much as $2 \mathrm{cc}$ and then taken to the UNDIP Cebior for ELISA examination according to the standards stated in the ELISA kit manual (Elabscience Catalog No E-MOO44 96T), then readings were carried out using the ELISA examination according to the standards stated in the ELISA kit manual (Elabscience Catalog No E-EL 
M0044 96T), then the reading was done using the BioRad Analyzer with a wavelength setting at $450 \mathrm{~nm}$.

\section{Isolation of Brain and Spleen of Mice and Bacterial Count}

Brain and spleen of the mice were also taken for the bacterial count in the Microbiology Laboratory of Diponegoro University. The brain and spleen organs were left for 30 minutes in a sterile organ tube, after frozen, they were put into $37^{\circ} \mathrm{C}$ incubator for 24 hours. Brain tissue and spleen were taken and weighed. Approximately 1 gram of the tissues was taken, crushed, and diluted with sterile with $1 \mathrm{cc}$ of $\mathrm{NaCl}$, the fluid was taken using numbered syringes and labeled treatment group. Dilution of bacteria from the sample fluids was made with physiological $\mathrm{NaCl}$ of $1 / 10,1 / 100$, and $1 / 1000$. Then each dilution was mixed into agar Nutrient media which had been heated to $40-45^{\circ} \mathrm{C}$ until a homogeneous mixture was formed. Media that had been mixed with a germicidal solution was poured into a sterile empty petri and then the number of MRSA bacteria was counted. The formula for counting the number of bacterial was the numberof colonies multiplied by dilution. Data on the number of bacterial counts were obtained through an assessment conducted by two experts with the clinical agreement (7).

\section{Data Analysis}

The research data were processed and analyzed using the SPSS 23.0 program for windows. Data analysis consisted of descriptive analysis and Independent T-test. The description data were obtained, and the normality test was done and obtained that the data were distributed abnormally, then the transformation is done using sqrt. The data were then continued to the independent T-Test test analysis to see the difference between the average paired groups (K1-P1, K2-P2, K3-P3). The Mann Whitney test was performed to test the differences in the bacterial count on the brain between the pair groups (K1-P1, K2-P2, K3-P3). There were no bacteria in the spleen.

\section{RESULTS}

Comparison of IL- 6 levels between the Control Groups and Treatment Groups

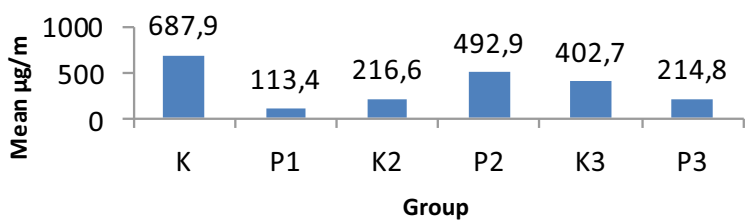

Figure 1. Bar graph of the mean of IL-6 levels in the control groups and treatment groups

Note: K1: Mice were infected with MRSA. P1: Mice were infected with MRSA and given thyme. K2: Mice were infected with MRSA and treated with vancomycin. P3: Mice were infected with MRSA and treated with a combination of thyme and vancomycin. K3: Mice were infected with MRSA and treated with amoxicillin. P3: Mice were infected with MRSA and treated with a combination of thyme and amoxicillin.

Figure 1 shows that the group given thyme (P1) had a smaller mean of IL-6 level compared to the group without thyme $(K)$, the group given vancomycin (K2) had a smaller mean of IL-6 level than the group given the combination of vancomycin and thyme (P2), and the group given amoxicillin (K3) antibiotics had a higher mean level of IL-6 than the group given the combination of amoxicillin and thyme (P3).

There were no differences in IL-6 levels among the control groups that were only infected with MRSA and the treatment group that was infected with MRSA and given thyme once with $p$-value $=0.086$. Among the group that were infected with MRSA and given antibiotics only and the group infected with MRSA and given a combination thyme and vancomycin or amoxicillin antibiotics $(p=0.136$; $p=0.692$ ). This finding infer that thyme has potential effect in reducing IL-6, put combination of thyme with antibiotic do not show additional benefit compared to antibiotic alone.

Table 1. Independent T-Test results of IL-6 levels of control and treatment groups

\begin{tabular}{lrrr}
\hline Treatment & Group & \multicolumn{1}{c}{ Mean \pm SD } & \multicolumn{1}{c}{$\mathbf{p}^{\S}$} \\
\hline Control (K1) vs Thyme (P1) & K1 & $6113,4 \pm 96,7$ & 0,08 \\
& P1 & $87,9 \pm 799,4$ & 6 \\
Vancomycin (K2) vs Vancomycin + & K2 & $216,6 \pm 111,6$ & 0,13 \\
thyme (P2) & P2 & $492,9 \pm 474,9$ & 8 \\
Amoxicillin (K3) vs Amoxicillin + & K3 & $402,7 \pm 580,3$ & 0,69 \\
thyme (P3) & P3 & $214,8 \pm 119,1$ & 2 \\
\hline
\end{tabular}

Note: $\S$ Independent t

K1: Mice were infected with MRSA

P1: Mice were infected with MRSA and given thyme

K2: Mice were infected with MRSA and treated with vancomycin

P2: Mice were infected with MRSA and treated with a combination of thyme and vancomycin

K3: Mice were infected with MRSA and treated with amoxicillin

P3: Mice were infected with MRSA and treated with a combination of thyme amoxicillin

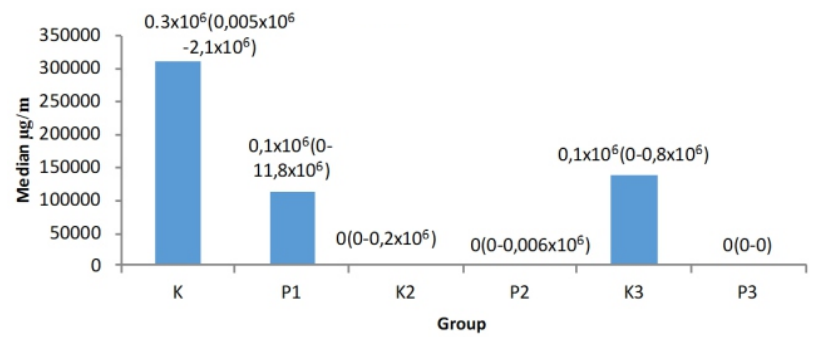

Figure 2. Median bar chart for the bacterial count in the brain of the control groups and the treatment groups

Note: K1: Mice were infected with MRSA. P1: Mice were infected with MRSA and given thyme. K2: Mice were infected with MRSA and treated with vancomycin. P3: Mice were infected with MRSA and treated with a combination of thyme and vancomycin. K3: Mice were infected with MRSA and treated with amoxicillin. P3: Mice were infected with MRSA and treated with a combination of thyme and amoxicillin.

Comparison of Bacterial Count in the Control Group Brain and Treatment Group from Figure 2 it can be seen that the results of the bacterial count in the brain show zero values in the group given vancomycin (K2), the group given vancomycin and thyme (P2), and the group given amoxicillin and thyme (P3). Because the data were found to be abnormally distributed, the Mann Whitney test was performed.

Mann Whitney's results in Table 2 show that there was no difference in bacterial count between the control group that was only infected with MRSA and the treatment group 
that was infected with MRSA and given thyme once $(p=0.347)$. In the vancomycin (K2) group and the thyme combination vancomycin group(P2), there was no significant difference in the decrease in the bacterial count because of the median results of the vancomycin group (K2) and the thyme combination vancomycin group (P2) were zero. The group given amoxicillin (K3) and the group given amoxicillin combination thyme (P3) had a significant difference in the decrease in bacterial count. The group given amoxicillin had zero results, thus there were no MRSA bacteria in this group. This shows that the administration of thyme alone does not provide a difference in the bacterial count, but a combination of thyme and antibiotics is better than antibiotics alone. The results of Bacterial count on the Spleen showed not bacteria in all groups.

Table 2. Distribution of the Mann Whitney test data on the bacterial count in the brain

\begin{tabular}{lrrr}
\hline \multicolumn{1}{c}{ Treatment } & Group & \multicolumn{1}{c}{ Mean \pm SD } & $\mathbf{p}^{\ddagger}$ \\
\hline Control (K) vs Thyme (P1) & & $\mathbf{Q}, 3 \times 10^{6}\left(0,005 \times 10^{6}-2,1 \times 10^{6}\right)$ & 0,347 \\
& P1 & $0,1 \times 10^{6}\left(0-11,8 \times 10^{6}\right)$ & \\
Vancomycin (K2) vs & K2 & $0\left(0-0,2 \times 10^{6}\right)$ & 0,700 \\
Vancomycin + thyme (P2) & P2 & $0\left(0-0,006 \times 10^{6}\right)$ & \\
Amoxicillin (K3) vs & K3 & $0,1 \times 10^{6}\left(0-0,8 \times 10^{6}\right)$ & $0,009^{*}$ \\
Amoxicillin + thyme (P3) & P3 & $0(0-0)$ & \\
\hline
\end{tabular}

Note: * Significant $(p<0.05)$; ¥ Mann Whitney

K1: Mice were infected with MRSA

P1: Mice were infected with MRSA and given thyme

$\mathrm{K} 2$ : Mice were infected with MRSA and treated with vancomycin

P2: Mice were infected with MRSA and treated with a combination of thyme and vancomycin

K3: Mice were infected with MRSA and treated with amoxicillin

P3: Mice were infected with MRSA and treated with thyme and amoxicillin combinations

\section{DISCUSSION}

The results showed the potential of Thymus vulgaris extract increases the antibacterial effectiveness of amoxicillin. The overall results showed that the highest average IL- 6 levels belonged to groups without thyme or antibiotics. This might be due to the manufacturing process of thyme extract determines the effectiveness of the content, the composition of the active ingredient of the thyme plant variant, the strength of antimicrobial effect of MRSA, thus causing the number of bacteria in the body of the mouse to decrease and the inflammatory response to be smaller. $(8,9)$ These results can also be influenced by the length of exposure and the duration of administration of thyme extracts and antibiotics that were too short that were only 42 hours; thus, proinflammatory cytokines had not been widely recruited by the body's defense mechanism. In previous studies, the dose of thyme used influences the effectiveness of the antibacterial active ingredient in killing bacteria. The differences in the content of active ingredients in different variants of thyme in each type affect the level of antimicrobial levels and the different content of active ingredients according to the age of the leaves used, such as young and old leaves that have different levels of active ingredients. Different ways of extraction (using methanol, ethanol, water or alcohol) affect the composition of the chemical mixture and its reaction to the microbial activity of thyme. In addition, differences in the extract part taken (using only the essential oil or using the whole extract and mixture) can affect the mechanism of action of the active ingredients of thyme (10).

According to Choy, in acute monocytes inflammation, macrophages and endothelial cells produce IL-6 which will lead to the recruitment of neutrophils through activation of the chemokine substance and adhesion of molecules by endothelial cells, smooth muscle cells, and fibroblasts. IL-6 causes neutrophil to defense longer through regulatory effects on neutrophil apoptosis. IL-6 induces the maturation of $B$ cells in plasma cells and has an impact on the natural immune response in which natural immune triger cell and stromal cells produce cytokines, chemokines, and other pro-inflammatory factors. The increase in the amount of IL- 6 in the acute phase is influenced by IL- 6 transignaling, simulation of gp 130 cell expression, the role of induction of fibroblasts, differentiation of Th17 cells, number of innate immune cells, presence of neutrophils, monocytes or macrophages. This can affect the role of IL- 6 in the acute and chronic inflammatory phases and can switch positions depending on the involvement of $B$ and $T$ cell activation and the use of pleiotropic effects (2).

The bacterial count examination showed results that the brain organ has a significant decrease in the number of bacteria between the groups given a combination of thyme and the group given only thyme or antibiotics alone. It is possible that thyme has efficacy as an effective antimicrobial for eliminating MRSA bacteria. Of the five treatment groups, the group combination of thyme and amoxicillin was the group that has the best results, so it is possible that the combination of thyme and amoxicillin has antimicrobial effects and is very potent in killing MRSA bacteria besides the use of vancomycin which is still sensitive in MRSA therapy. The administration of thyme increases the performance of amoxicillin that has been resistant as evidenced by the result that a single administration of amoxicillin does not kill bacteria completely, but with the addition of thyme, the bacteria can be eliminated (11).

The thyme content combined with amoxicillin can turn cell size smaller and lesser and make the cell wall swell and irregular distribution of the cytoplasmic membrane, so it can make the cell wall dirty and dense that allows the induction of empty area in the cell. Components of thyme extract that can penetrate into the fat layer of cell membranes of bacteria and mitochondria cause the loss of organizational structure and cell integrity. Thyme can synergize with amoxicillin in reducing the number of MRSA bacteria by increasing the effectiveness of antibiotics $(12,13)$. In addition, thyme can revive the antimicrobial potential of amoxicillin that was previously known as an antibiotic-resistant to MRSA. According to El Kalek 2012, amoxicillin combination with thyme extract can inhibit the growth area of MRSA bacteria in vitro examination. Thyme extract can also increase amoxicillin activity against MRSA bacteria. The content of thyme herbal oil can inhibit $\beta$ lactamase deformation and can be recognized. The combination of thyme and amoxicillin destroys the defense of MRSA strains on cell membrane permeability or genetic factors. Phytochemicals in thyme extract may play a role in the bacterial plasma membrane and affect the efflux pump (14).

In this study, the administration of vancomycin alone or in combination with thyme can eliminate bacteria in the brain, 
indicating that there is no resistance to vancomycin. In the Hossan study, they used Cinnamomum cassia plant extract containing Cinnamaldehyde and eugenol to fight MRSA bacteria, in this study cinnamaldehyde could increase MRSA sensitivity to vancomycin, but if combined they did not provide the same effect. The difference in our research is that the type of plant extract used was different. Hossan MS used Cinnamomum cassia, and the solvent used was hexane and MRSA $10 \%$ (CFU/mL). In this study, Thymus vulgaris plant extracts and methanol solvents were diluted with Carboxymethylcellulose (CMC) to reach a concentration of $20 \mathrm{mg} / \mathrm{ml}$. The bacteria used were MRSA strain ATCC 43300 dose of $0.2 \mathrm{ml}$ (107 CFU/ml) (15).

On the examination of the bacteria count on the spleen organs obtained the same results among groups given thyme alone or groups that were only given antibiotics and groups that were given a combination of thyme and antibiotics were not found any bacteria. This is possible because the spleen is the organ of the Reticulo Endothelial System (RES) which functions to consume bacteria and multiply when infection occurs, process antigens, and stimulate plasma cells to make antibodies (15). In the spleen organ, the high number of macrophages allows macrophages to kill MRSA bacteria effectively through the bloodstream, so that MRSA bacteria do not develop much in the spleen. Spleen macrophages adapt to be able to recognize and destroy

\section{REFERENCES}

1. Kurniawati AFS, Satyabakti P, and Arbianti N. Perbedaan Risiko Multidrug Resistance Organisms (MDROS) Menurut Faktor Risiko dan Kepatuhan Hand Hygiene. Epidemiologi. 2015; 3(3): 277-289.

2. Choy E and Rose-John S. Interleukin-6 as a Multifunctional Regulator Inflammation, Immune Response, and Fibrosis. Journal of Scleroderma Related Disorder. 2017; 2(2): s1-s5.

3. Kok EY, Vallejo JG, Sommer LM, et al. Association of Vancomycin MIC and Molecular Characteristics with Clinical Outcomes in Methicillin-Susceptible Staphylococcus aureus Acute Hematogenous Osteoarticular Infections in Children. Antimicrobial Agents and Chemotherapy. 2018; 62(5): 1-10.

4. Boskovic B, Zdravkovic N, Ivanovic J, et al. Antimicrobial Activity of Thyme (Thymus vulgaris) and Oregano (Origanum vulgare) Essential Oils Against Some Food-Borne Microorganisms. Procedia Food Science. 2015; 5: 18-21.

5. Ocana A and Reglero G. Effects of Thyme Extract Oils (from Thymus vulgaris, Thymus zygis, and Thymus hyemalis) on Cytokine Production and Gene Expression of Oxldl-Stimulated THP-1Macrophages. Journal of Obesity. 2012; 2012: 1-11.

6. Departemen Farmakologi dan Terapeutik Fakultas Kedokteran Universitas Indonesia. Farmakologi dan Terapi oleh Departemen Farmakologi dan Terapeutik Fakultas Kedokteran Universitas Indonesia. Edisi 5. Jakarta: Departemen Farmakologi dan Terapeutik Fakultas Kedokteran Universitas Indonesia; 2008: p. 728. bacteria that have been opsonized. In this opsonization, the bacterial surface is covered by spleen opsonization complement or molecules such as properdin and tuftsin, which then interact with receptors in phagocytosis (16). based on some experimental studies, the location of antigens in lymphoid organs depends on several factors, such as port d'entry of antigens, determine the localization of antigens in lymphoid tissue, specifically for foreign particles, proteins, and macromolecules such as lipopolysaccharides (LPS). Furthermore, intravenous administration of antigens results in the accumulation of antigens in the spleen, so the spleen is referred to as the main organ that responds to blood-borne antigens (17).

This study had not used variations in the dose of thyme extract and antibiotics to find the right dose. Lack of blood sample made the blood bacteria count unable to be conducted. The use of commercial thyme simplicia and ignoring the age of the leaves can cause the thyme leaves used to become heterogenous which must be considered in the interpretation of the results of this study.

The results of this study prove the potential of thyme leaves as a combination therapy with amoxicillin antibiotics in the case of MRSA. Further studies are needed by adding bacterial count indicators on blood and consider the age of thyme leaves used to increase the similarity of the tested thyme content.

7. Valencia L. Pengaruh Pemberian Terapi Minyak Nigella sativa dan Kombinasinya dengan Sefriakson terhadap Jumlah Kuman Methicilin Resistant Staphylococcus aureus (MRSA) pada Kultur Limpa Mencit Balb C. [Thesis\}. Jurnal Kedokteran Diponegoro.

8. Gordon RJ and Lowy FD. Pathogenesis of Methicillin Resistant Staphylococcus aureus Infection. Clinical Infectious Diseases. 2008; 46(5): S350-S359.

9. Arshad N, Mehreen A, Liaqat I, Arshad M, and Afrasiab H. In Vivo Screening and Evaluation of Four Herbs against MRSA Infection. BioMed Central Complementary and Alternative Medicine. 2017; 17(1): 1-7.

10. Sienkiewicz $M$, Lysakowska $M$, Denys $P$, and Kowalczyk E. The Antimicrobial Activity of Thyme Essential Oil against Multidrug Resistant Clinical Bacterial Strains. Microbial Drug Resistance. 2012; 18(2):137-148.

11. Uzair B, Niaz N, Bano AS, et al. Essential Oils Showing In Vitro Anti MRSA and Synergistic Activity with Penicillin Group of Antibiotics. Pakistan Journal of Pharmaceutical Sciences. 2017; 30(5): 1997-2002.

12. Borugă $\mathrm{O}$, Jianu $\mathrm{C}$, Mişcă $\mathrm{C}$, Goleţ I, Gruia AT, and Horhat FG. Thymus Vulgaris Essential Oil: Chemical Composition and Antimicrobial Activity. Journal of Medicine and Life. 2014; 7(3): 56-60.

13. Kon K and Rai M. Antibacterial Activity of Thymus vulgaris Essential Oil Alone and In Combination with Other Essential Oils. Nusantara Bioscience. 2012; 4(2): 50-60.

14. ElKalek A and Mohamed E. Synergistic Effect of 
Certain Medicinal Plants and Amoxicillin against Some Clinical Isolates of Methicillin Resistant Staphylococcus Aureus (MRSA). International Journal of Pharmaceutical Applications. 2012; 3(3): 387-398.

15. Hossan MS, Jindal H, Maisha S, et al. Antibacterial Effects of 18 Medicinal Plants Used by the Khyang Tribe in Bangladesh. Pharmaceutical Biology. 2018; 56(1): 201-208.

16. Abbas AK, Lichtman $\mathrm{AH}$, and Pillai S. Basic
Immunology: Functions and Disorders of the Immune System. 5th edition. Philadelphia, USA: Saunders/Elseviers; 2015.

17. Yazaki M, Oami T, Nakanishi K, Hase R, and Watanabe HA. Successful Salvage Therapy with Daptomycin and Linezolid for Right-Sided Infective Endocarditis and Septic Pulmonary Embolism Caused by MethicillinResistant Staphylococcus aureus. Journal of Infection and Chemotherapy. 2018; 24(10): 845-848. 